\title{
ORTHOTOLIDINE HYDROCHLORIDE TEST FOR BLOOD IN URINE
}

\author{
BY \\ H. ZWARENSTEIN \\ From the Department of Physiology and Pharmacology, University of Cape Town
}

(RECEIVED FOR PUBLICATION, DECEMBER 1, 1948)

In 1943 the author described a test for blood in urine in which small squares of filter paper impregnated with $o$-tolidine were used. The papers, however, deteriorated within a few months. This disadvantage has now been overcome by using solid $o$-tolidine hydrochloride instead of the papers.

\section{Reagents}

$o$-Tolidine hydrochloride. Acid-peroxide solution. Equal volumes of glacial acetic acid and 3 per cent hydrogen peroxide (freshly diluted from 30 per cent). The mixture is allowed to stand for twenty-four hours before using. The solution should be freshly prepared every three months.

\section{Procedure}

A small knife-point (about $3 \mathrm{mg}$.) of solid $o$-tolidine hydrochloride is placed on a clean white porcelain tile. One drop of urine is added and thoroughly mixed with the solid by stirring with a glass rod. One drop of acid-peroxide solution is added.

\section{Reactions}

Negative reaction.-A light brown colour slowly develops. Occasionally one or two large blue dots appear. These must be disregarded.

Positive reactions. - (a) Numerous small greenish-blue dots develop within a few seconds. Sometimes the dots are drawn out into greenishblue streaks. The dots or streaks persist for periods varying from ten to thirty seconds to several minutes according to the amount of blood present. They then fade and disappear and a light brown colour develops. Reaction $(a)$ is the typical reaction for occult blood (red cells) in urine.

- (b) When a large amount of blood is present, such as 1,000 red cells per c.mm., a dense, dark blue colour appears immediately. The dark blue mass is surrounded by yellowish-green areas. The colour may persist for half an hour or longer.

(c) If free haemoglobin is present a diffuse greenish-blue to dark blue colour appears which persists for a varying length of time and then fades.

False positive reactions.-Bromides and iodides in the urine give positive reactions. These will obscure the reactions for blood in a urine which contains both blood and bromides or iodides. Bromides give a diffuse greenish to greenish-blue colour which develops slowly and then fades. The reactions given by iodides are similar to the blood reactions $(b)$ and $(c)$ described above. Small amounts of iodides give a greenish-blue colour which also quickly fades to a light brown colour.

A true positive reaction due to blood can be distinguished from a false positive reaction due to bromides or iodides as follows.

A few $\mathrm{ml}$. of urine are boiled for about one minute and then cooled, and the test is repeated. If blood is present the second test will be negative or the colour will be reduced in intensity according to the amount of blood originally present. Urines which contain as many as 1,000 red cells per c.mm. show a decreased reaction after boiling. Iodides and bromides, even when present in small amounts, are unaffected by boiling. Therefore if a positive reaction is decreased or is negative when the test is repeated after boiling, it can only be due to the presence of blood.

Pus gives a negative reaction unless it is present in such large amounts as to cause an obvious turbidity.

It has been reported that an excess of ascorbic acid in urine inhibits the benzidine blood test (Kohn and Watrous, 1938) and also the o-tolidine test performed on the centrifuged deposit (Barach and Pennock, 1940). The author has found that it also inhibits the $o$-tolidine hydrochloride test described above, and as a result small amounts of blood will give a negative reaction in the presence of an excess of ascorbic acid.

\section{Sensitivity of the Test}

In the experiments for determining the sensitivity of the test it was assumed that the blood 
used contained 5 million red cells per c.mm. and $15 \mathrm{~g}$. haemoglobin per $100 \mathrm{ml}$. This is a sufficiently close approximation for the purpose of assessing the sensitivity of a qualitative test.

1. Haematuria $-0.1 \mathrm{ml}$. 'of blood was pipetted into about $90 \mathrm{ml}$. of 0.9 per cent sodium chloride and made up to $100 \mathrm{ml}$. with saline. Serial dilutions were then prepared with normal urine and the o-tolidine hydrochloride test performed on the urines containing various concentrations of red cells.

It was found that a concentration of 1 red cell per c.mm. ( $=$ a dilution of 1 in 5 million) gave a negative result. A urine containing 2 red cells per c.mm. gave a slight but definite positive reaction ; a concentration of 5 red cells per c.mm. ( $=$ a dilution of 1 in one million) gave a comparatively strong positive reaction. According to Stone and Burke (1934), who applied an o-tolidine test to centrifuged deposits of urine, the persistent excretion of more than 1 red cell per c.mm. of urine is of clinical significance and merits further investigation. They found that red cells are not ordinarily detected with the microscope until their number exceeds 5 per c.mm. of urine. The $o$-tolidine hydrochloride test is therefore more sensitive than the microscopical test and its sensitivity is such that a slight but definite positive reaction is of pathological significance.

2. Haemoglobinuria $-0.1 \mathrm{ml}$. of blood was pipetted into about $90 \mathrm{ml}$. of distilled water and made up to $100 \mathrm{ml}$. with distilled water. Serial dilutions were prepared with normal urine and the various dilutions tested.

The smallest amount of free haemoglobin detectable in urine was found to be $150 \mu \mathrm{g}$. per $100 \mathrm{ml}$. (the equivalent of a dilution of 1 in 100,000 or 50 red cells per c.mm.). On spectroscopic examination the smallest amount of haemoglobin detectable was $2.4 \mathrm{mg}$. per $100 \mathrm{ml}$. (equivalent of
800 red cells per c.mm.). The examination w苟 made with a direct-vision spectroscope through a layer of urine two inches thick.

The $o$-tolidine hydrochloride test is, thus, moje sensitive than the microscopiçal test for red cefs and about sixteen times more sensitive than the spectroscopic test for free haemoglobin. It $\overline{\text { is }}$ about twenty-five times more sensitive for red cels in suspension than for free haemoglobin $f$ solution.

\section{Summary}

1. A simple chemical test for blood in urine $\$$ described. Solid o-tolidine hydrochloride is useed for the test, which is performed with one drop of urine and one drop of an acetic acid-hydrogen peroxide mixture.

2. After boiling, urines containing blood give 9 decreased or negative reaction. Iodides and bromides, which also give positive reactions, a unaffected by boiling.

3. Pus gives a negative reaction unless it $\dot{\mathrm{g}}$ present in such large amounts as to cause an obvious turbidity.

4. Excess ascorbic acid decreases the sensitivi of the test.

5. The test is more sensitive than the micr苨 scopical test for red cells and about sixteen times more sensitive than the spectroscopic test for fre haemoglobin. The smallest number of red cells detectable is 2 per c.mm. and the smallest amoug of free haemoglobin detectable is $150 \mu \mathrm{g}$. per. $100 \mathrm{ml}$.

\section{REFERENCES}

Barach, J. H., and Pennock, L. L. (1940). J. Amer. med. Ass., 1표, 640.

Kohn, R., and Watrous, R. M. (1938). J. biol. Chem., 124, 163O

Stone, W. J., and Burke, G. T. (1934). J. Amer. med. Ass., 102, 1549.

Zwarenstein, H. (1943). Clin. Proc., 2, 125. 